\title{
'What Has Rome to do with Bethlehem?' Cultural Capital(s) and Religious Imperialism in Late Ancient Christianity
}

\author{
Andrew S. Jacobs*
}

The re-evaluation of classical education (paideia) recurred throughout the Roman period, reaching a particularly fevered pitch during the late fourth century, as the empire became Christian. The political consequences of Christian learning become particularly clear in the debate between two learned, Latin-speaking Christians who translated Greek works: Jerome and Rufinus. In the course of their acrimonious conflict over the theological legacy of Origen, these two prominent intellectuals resorted to name-calling: Jerome accused Rufinus of being unlearned, and Rufinus claimed that Jerome's erudition signalled impiety. These accusations over education, culture, and linguistic expertise convey a deeper anxiety over the nature of knowledge and power at the dawn of the Christian Roman Empire. To what extent can Christians appropriate and transform the knowledge of 'others'? When is translation an act of piety and when it is an act of hubris? What kinds of cultural capital will be valued in a newly Christian world, where classical paideia is valued and held suspect at the same time?

\section{Paideia}

In his I964 novel fulian, Gore Vidal imagined the University days of his eponymous subject, Julian the Apostate, in Athens: trading Aristotelian witticisms with Gregory and Basil (future bishops from Cappadocia), romancing (and impregnating) his professor's niece, covering for Gregory when he is caught stealing scrolls from the library: 'I remember every one of the forty-seven days I spent in Athens,' Vidal has Julian recall. 'They were the happiest of my life, so far' (Vidal ig64: I26). In the imaginary Athens of Vidal's Julian, culture, education, and religion are inseparable: not only does Basil debate the Virgin Birth with Cynics 'on the

\footnotetext{
*Correspondence to Scripps College - Religious Studies, ıо30 Columbia Avenue, \#4005 Claremont, CA 9I7I I, USA. ajacobs@scrippscollege.edu

A version of this essay was delivered at the 'Jerome of Stridon' conference in Cardiff, Wales, in 2006; an even earlier iteration was presented at the North American Patristics Society in I998. I thank Elizabeth A. Clark, Catherine M. Chin, Mark Vessey, and Adam Kamesar for helpful advice on this essay over the years, and additional gratitude to the anonymous reviewers for this journal.
} 
University steps' (Vidal I964: I38-9), ${ }^{\mathrm{I}}$ even the curses of the working girls at the Dipylon Gate aggressively marketing to Julian upon his arrival are 'vivid and splendid, Homeric!' (Vidal I964: I29) The entire city of Athens is infused with paideia, contributing with every stone and prostitute to the formation of an educated ruling class. $^{2}$

It would be quite useful if we could, like Vidal, revive so imaginatively the social contexts in which classical paideia was reproduced in the late Roman Empire, to peer over the shoulders of Roman schoolboys in order to chart their growth into aristocratic men of culture. The formative and socializing role of paideia took on new urgency precisely in the 'salad days' of Julian and the Cappadocian Fathers. As Christians developed a sense of public identity in the fourth century, paideia became both a tool and a danger; a sense of common cultural heritage could forge a new sense of Christian power and status or it could divide Christians in new and complex fashion. Sophisticated theological debate, for instance, would not have been possible without the philosophical language drawn from educated Greek culture: discussions of 'persons' (hypostaseis) and 'substances' (ousiai) are given rhetorical and philosophical shape from classical paideia. ${ }^{3}$ At the same time, paideia could come to be viewed with suspicion as a repository of non-Christian — that is, 'pagan' —ideas and mores. ${ }^{4}$

It was not only the grand ideas of paideia that created and dissolved religious and cultural loyalties among post-Constantinian Christians. Like the prostitutes hurling Homeric insults at Vidal's Julian, late ancient Christians often drew their sense of (and opposition to) culture from the most minute processes of cultural formation. 'What has Jerusalem to do with Athens?' asked Tertullian (the well-educated, bilingual North African Christian) already in the late second century. 'What relation does the Academy have with the Church?' (De praescriptione haereticorum I.I) By the fourth century, this tension had not dissipated: well-educated Christians continued to, by turns, appropriate and reject paideia, culture, as grounds for their religious authority. ${ }^{5}$

Two figures in particular, equally well known for their education and theological rancour, make manifest the host of tensions surrounding Christian translation of

I Basil adduces the virgin conception of vultures, supposedly drawn from Aristotle (but probably from the spurious De mirabilibus auscultationibus). On this motif in classical through medieval literature, see Zirkle 1936.

2 On school bonds of friendship, see Watts 2006: 7-9.

3 See Ayres 2004: 198-202. The term hypostasis is notoriously difficult to render in English, especially in the context of Christian Trinitarian debates. It clearly bears the sense of 'independent reality', and in Latin theology is usually translated as persona; 'subsistence', while literal, is not particularly helpful. See, generally, Ayres 2004: 25-6, 92-8 209-I I.

4 On this complex process, see Chin 2007.

5 So Jerome writes in memory of his friend Paula: 'she preferred Bethlehem to Rome, and exchanged a mansion glittering with gold for the meanness of a shapeless clay hut' (ep. I08.I.I). 
paideia in the late ancient world. Jerome and Rufinus were schoolmates in Aquileia, later friendly correspondents in the monastic endeavour, finally bitter rivals and literary enemies launching polished polemical treatises at each other across the Mediterranean world like Latinate missiles. As many studies have shown, their hostility was infused with personal as well as religious passion: ideas about human salvation and ascetic transformation merged with ecclesiastical ambition and jealousy (Clark 1992). Their debates were also, I contend, cultural and political. Attention to the politics of erudition in this fourth-century dispute can illuminate for us the shifting frontiers of religion and empire in their late fourth-century Christianizing context.

French sociologist Pierre Bourdieu famously critiqued institutional forms of knowledge production - education and 'culture' - as a conservative means of marshalling and retaining class power: the fine and often concealed interpenetrations of material and cultural 'capital' (Bourdieu I977: I 7 I-83; Bourdieu and Passeron I977: 30; Bourdieu I984: 53-4; Bourdieu I993: 43-5). For the ancient gentlemen inducted into the timeless fraternity of paideia, such an observation would be common sense: in a strictly stratified society, the cultural patrimony of Homer, Plato, Vergil, and Cicero was understood to belong properly to the ruling classes. ${ }^{6}$ The seemingly timeless workings of cultural capital were not without friction, however. As Rufinus and Jerome hurled learned accusations at each other during their 'Origenist controversy,' we see at work a tension over the limits of Christian empire at the intersections of politeia and paideia, between political and cultural capital.

\section{Capital(s)}

The debate began with translation, when Rufinus modestly invoked his 'brother and colleague' (not named, but clearly Jerome) in the preface to his emended translation of Origen's Peri archōn. ${ }^{7}$ That Rufinus was being somewhat provocative and mischievous is clear: ${ }^{8}$ he portrays himself as continuing Jerome's own translation project, since the latter 'taking such delight in his own style, pursues a matter of greater glory - that he might be the father of the word, rather than just its translator' (pater verbi sit potius quam interpres) (Rufinus, Praefatio in Periarchōn I.I). The ensuing

6 Watts 2006; Kaster i988; Cameron i998; Too 200 I.

7 Origen's treatise On First Principles addressed issues of cosmogony, Trinity, salvation, Scriptural interpretation, and theodicy in highly speculative but systematic fashion. Its appeal to Latin readers in the later fourth century seems to have been related to its answers to questions of theodicy and human participation in salvation: see Clark 1992: I I-I 2 .

8 Courcelle i969: ı speaks of Rufinus taking 'malicious delight. . . in posing as continuator of Jerome's vast design.' Jerome was alerted to Rufinus's invocation of his work by friends in Rome (Pammachius and Oceanus): 'Subtly in the preface to his own work he has made reference to your sanctity without mentioning your name, saying that he has completed a work promised by you' (Jerome, ep. 83.2). 
fracas between the two erstwhile schoolmates centred on the theological appropriateness of Origen. ${ }^{9}$ But that initial casus belli - the task of translation, from Greek to Latin-kept insinuating itself. To some modern readers, the issue of translation might seem a strange hook for such a wide-ranging debate: a mechanical procedure, requiring merely enough time and resources to master new symbols and rules. It is, of course, in precisely such 'mechanical' processes that Bourdieu located the faceless reproduction of cultural capital: because it seems so rote, so open, educated tasks like translation mask the presence of material status: 'Symbolic capital, a transformed and thereby disguised form of physical "economic" capital, produces its proper effect inasmuch, and only inasmuch, as it conceals the fact that it originates in "material" forms of capital which are also, in the last analysis, the source of its effects' (Bourdieu I977: I83). ${ }^{\text {Io }}$ It might seem everyone could master a foreign language, but everyone does not.

In the early Roman Empire, the ability to translate Greek into Latin represented a source of negotiable linguistic and cultural capital. ${ }^{\text {I I }}$ Aristocrats could frame their intellectual superiority in terms of an erudite bilingualism that demonstrated intellectual and political mastery. ${ }^{\mathrm{I} 2}$ By the time Jerome and Rufinus were schooled, such bilingual erudition no longer prevailed among the educated elites of the Latin West. Symmachus, the late fourth-century Roman aristocrat, famously (and somewhat ambiguously) referred to re-learning forgotten Greek with his son (ep. 4.20.2: Dum filius meus Graecis litteris initiatur, ego me denuo studiis velud aequalis adiunxi); and Augustine, in an equally rhetorical fashion, bemoaned his inability to learn Greek (Confessiones I.I3.20, I.I4.23). The shadow of Greek erudition nonetheless lingered in Latin education, perhaps less as a bilingual goal than a fond reminiscence: the surviving grammatical handbooks of Jerome's own teacher, Donatus, preserve

9 Clark I992: I I-I 7, I 2 I-5 I, I 59-93.

Io See also Guillory 1993 and now, on Jerome, Williams 2006.

I I On 'cultural capital', see Bourdieu I99 I: 57-65.

I2 The question of ancient 'bilingualism' is perhaps too often analogized to modern, globalized linguistic situations. Two factors in the study of Roman knowledge of Greek are important to keep in mind: the very textual nature of Roman bilingualism (i.e., it is unclear how frequently Romans conversed, or even desired to converse, in Greek; although Jerome does claim his companion Paula's last words were in Greek (ep. I08.28.2), their situation was in many ways atypical) and the asymmetrical power dynamics involved in multilingual imperial contexts. For helpful overviews, see Kaimio I979: I95-33I; Rochette I995; Biville 2002; and Swain 2002, who makes subtle use of cultural linguistics in his analysis of late Roman Republic 'bilingualism'. That Bourdieu's ideas on translation and cultural capital might be useful in analysing the power dynamics in modern translation is the subject of multiple essays in Wolf and Fukari 2007. 
exempla that suggest, but do not require, knowledge of Greek language and literature. ${ }^{\text {I3 }}$ So knowledge of Greek, while perhaps increasingly rare on the ground, retained some cultural value among Roman elites. Jerome, therefore, toiling to acquire social status in Rome, could portray himself as an educated gentleman of the 'old school'. ' 4

As part of his literary persona, Jerome invoked the sentiments of Cicero and Horace, for whom translation was an oratorical art of appropriation and reconfiguration (Cicero, De optimo genere oratorum $4 . \mathrm{I} 4$ and De finibus bonorum et malorum 3.I4. I5; Horace, Ars poetica I33-4; see Seele I995: 89-Ior; Swain 2002). When a translation from Greek, of a letter of Epiphanius of Salamis, was criticized for its looseness, Jerome penned a treatise 'On the Best Method of Translating' (the title of which was meant to recall Cicero's treatise on orators: Bartelink I980). In this letter on translation, Jerome invokes a series of classical translators (I include here his extended citation from Cicero):

Not only do I myself confess, but in a free voice I proclaim, that in the translation of Greek (except of Holy Scriptures, where even the order of the words is a mystery) I do not simply express word for word (verbum e verbo), but sense for sense. And for this matter I have as my instructor Cicero (magistrum Tullium), who translated Plato's Protagoras, and Xenophon's Oeconomicus, and the two beautiful speeches Aeschines and Demosthenes delivered to each other. How much in this he omitted, how much he added, how much he changed, so that he might explain what was idiomatic in another language (proprietates alterius linguae) in his own idioms, there is not the time to tell. But the authority itself of the translator is enough for me, who spoke thus in the prologue of these speeches: 'I considered that I should undertake a labor useful for those who are eager (studiosis), even though it was not necessary for me. So I translated (converti) the most noble speeches of two of the most eloquent from among the Attic orators, which were delivered in response, Aeschines and Demosthenes. But I did not translate as an interpreter but as an orator (nec converti ut interpres sed ut orator), with the same ideas (sententiis) and their forms as well as figures of speech, with the words shaped to our own usage (verbis ad nostram consuetudinam aptis). In this I held it necessary to render not word for word, but I kept the type (genus) and force of all of the words. For I did not think that I had to present these [words] to the reader by counting them out, but rather, as it were, by weight' (Cic. de opt. I3-I4). Again, at the end of his discourse, he says: 'If I myself, as I hope, have thus expressed using all of their own strengths, that is, their ideas and their figures and order of things, following their words to the extent that they do not offend against our manner (ea non abhorreant a more nostro), if they are not all translated from the Greek, nonetheless, I have taken pains to ensure that they are of the same ilk' and so forth (Cic. de opt. 23). But also Horace, a sharp and learned man, teaches this same thing in his Ars poetica concerning the learned interpreter: 'You should not be concerned, as a faithful

I3 Donatus, Ars minor 4 (on the optative mood); Ars maior I.2 (Greek letters), I.5 (accents), 2.3 (Greek names), 2.9 (Greek cases), 2.Io (declensions of Greek loan-words), 2.I7 (Greek interjections). The text of Donatus, and important commentary, are found in Holtz I98I; see also Chin 2007: I I-38.

I4 On Jerome's status see Clark I979: 6I-4; Rebenich I992: I54-92. 
interpreter (fidus interpres), to render word for word' (Ars poetica I33-34). Terence translated Menander, Plautus and Caecilius the older comic playwrights. Did they stick to the word or rather did they not rather preserve decorum and elegance in their translation? What you dub 'true translation' (veritatem interpretationis), the learned call kakozēlia ('fussiness'). (ep. 57.5.2-5; see Bartelink I980: 44-7)

As this long passage makes clear, Jerome was intent on securing his place as an intellectual enricher of Christian paideia, and one mode for doing so explicitly invoked the cultural riches of his Latin Roman past, a tradition that displayed original genius through translational artistry. ${ }^{\mathrm{I}}$

Jerome was not a literary theoretician in the style of Cicero or Horace, however (Adler I994). What Jerome found compelling in the art of translation was its demonstrative worth in the public sphere: the cultural capital it brought to him as a Christian man of letters. Even in this he remained Cicero's pupil. For wealthy Romans, the vehicle of Greek-language education was slaves and freedmen imported-like expensive lexica_-into the city of Rome (Kaimio I979: 322-3 I; Corbeill 200I). Horace phrased it, perhaps, more artfully: 'Captive Greece captured the beastly victor and brought the arts to rustic Latium' (Horace, Epistularum liber 2.I. 156-7). That Graecia was captive added to the value of its literary spoils, and created a dialectic of Roman power and Greek knowledge throughout the early imperial period. ${ }^{\text {I } 6}$

This Christianization of a classical past in late antiquity was not unique to Jerome. Scholars have often looked to the rise of an educated Christian elite as a moment of cultural transformation, for both Christianity and classical paideia. Catherine Chin has shown that articulating a 'classical' past was a common task of Christian and non-Christian literati of this period: crafting a literary patrimony articulated out of the reconstituted bits and pieces of the 'classical' authors from which pagan and Christian identities could be drawn (Chin 2007). The value of bilingualism itself, as we see in Jerome's homage to Cicero, similarly emerges out of this reconstituted 'classical' past: the legacy of Cicero and Horace who had themselves appropriated and mastered a 'classical' Greek literary antiquity.

Yet, as Chin also points out, even a shared intellectual history could generate social friction. Translation, clearly, offered both Jerome and Rufinus a means of acquiring cultural capital: both of relatively obscure origins, by the end of the fourth century they were known to the intellectual elite classes across the Mediterranean world (Vessey 2004). Yet this cultural capital-bilingual translations for Latin Christian readers-held vastly different value for these two former schoolmates. Certainly both of them saw translation as a worthwhile project, contributing to the

I5 On translation as art in this period and beyond, see Brock I979 and Brown I993.

I6 The politics of paideia are particularly evident in the dynamics of the so-called 'second sophistic', a highly artificial, Atticizing movement among Greek provincials in the first centuries of the Roman Empire: see Goldhill 200I; Whitmarsh 200I; Whitmarsh 2005; on the material effects and artifacts of this politics of paideia, see Nasrallah 20 го. 
production, and reproduction, of Christian knowledge. But they differed on the broader political ramifications of this means of production.

\section{Jerome's capital}

Jerome, in the late fourth century, sought to give the tradition of multilingual cultural capital a Christian flavour, casting himself and Christianity as the new 'victors' in a new Christian Empire. Jerome invokes bilingual Christians such as Hilary of Poitiers, who he claims preceded him in the translation of Origen's homilies:

He turned homilies on Job and many tractates on the Psalms from Greek into Latin; and he didn't content himself with the sleepy letter, nor twist himself with the affected translation of the uneducated; but as if they were his captives, by right of a conqueror (victoris iure), he carried off the meanings into his own language (ep. 57.6). ${ }^{17}$

Cicero had trotted out Plato captus; now Christian intellectuals (like Hilary or Jerome) could trade on the value of Origenes captus. What Jerome suggested, in his early translational efforts of the 380 os and 390 , was not a consistent translational theory but rather a politics of erudition. Jerome set out to produce a form of Christian knowledge that replicated the political mastery of the Roman Empire.

Translation was a particularly apt vehicle for this project, preserving as it did the 'otherness' of the 'captive' knowledge so reproduced. The cultural economy of the Roman Empire was distinct from its Hellenistic predecessor in its desire to preserve heterogeneity within its domain. Instead of demanding a uniform cultural language that homogenized difference and enforced central domination, Roman power was predicated on the retention of difference: the ostentatious display of power that was only possible if the conquered subject remained visibly 'other'. We can see this thread weaving through articulations of Roman authority from the late Republic onward: the triumphal march, the arena filled with minimally domesticated exotica (both animal and human), the 'Syrian Orontes' flowing into the Tiber (as Juvenal complained: Sat. 3), its eastern influence never quite integrated into Rome (Edwards and Woolf 2003). The absorption of other knowledge through translation could likewise signal Roman mastery, especially if that knowledge retained a sense of its otherness: 'captive meanings,' forced to march in Latin time. ${ }^{\text {I8 }}$

Jerome, crafting an authoritative religious persona at the dawn of the Christian Roman Empire, found such a model of ostentatious mastery useful (Vessey i993; Cain 2009). During his sojourn in Syria and Constantinople, he had acquired an increasingly rare coin in the accumulation of cultural capital: working knowledge of Greek, which allowed him to begin producing, from the early 380 os onward, Latin translations of otherwise inaccessible Greek Christian texts. His first such project was the rather artless, yet technically complicated, translation of Eusebius's

I7 The verb transfero used here can bear the sense of 'carrying off into captivity' or even 'bearing as spoils in a triumph.'

I8 On a related phenomenon of interpretatio in Roman religion, see Ando 2008: 43-58. 
Chronicon; ${ }^{\text {I9 }}$ yet he already invokes in his preface to that work the 'classical' model of Cicero's translation:

Of old was it the custom of learned men (disertorum mos fuit), that, for the sake of exercising their minds, they rendered Greek books in Latin speech and, that which is even more difficult, translated the poems of famous men, with the added constraint of meter. Whence even our Cicero (noster Tullius) translated entire books of Plato ad verbum (Chronices praefatio; see Williams 2006: 45-62).

Jerome was, to be sure, not the only bilingual Roman Christian on the scene, but he made a special point of highlighting the foreignness of his sources. In the preface to his translation of Didymus the Blind's treatise on the Holy Spirit, Jerome contrasts his own straightforward (and muscular) translation with the paltry and feminized efforts of others who did not acknowledge appropriately their Greek sources. The issue for Jerome is not simply dishonesty (passing another's words off for one's own), but the cultural capital to be gained in promoting the fact of translation into Christian Latin:

And I have confessed the author in my title: I preferred to be the translator of another's work, rather than (as some people do) to adorn myself in another's colours, like a misshapen little crow. A while back I read the books of a certain person on the Holy Spirit: and, as the Comic says, 'I saw not very good Latin made out of good Greek' (Terence, Eunuchus prol. 7-8). There is no philosophical reasoning (dialecticum), nothing manly and rigorous (virile atque districtum), which draws the reader into agreement even against his will: but it's all flaccid, soft, shiny and pretty, and with the choicest hints of colours dabbed here and there (De spiritu sancto Didymi Alexandrini praefatio). ${ }^{20}$

Apart from sheer cattiness, this preface to Jerome's translation conveys what the monk found so appealing about the cultural capital of erudite translation: the authority it granted, not only to Jerome himself, but to the production of Christian knowledge in general. Jerome represents the translation of Greek into Latin as an act of Christian virilitas. To hide the appropriation of other knowledge is to perform some kind of emasculating linguistic drag, ineffectively mimicking instead of masterfully seizing. ${ }^{2 \mathrm{I}}$ Jerome's triumphal translations reproduce a manly, and Roman, form of textual authority.

Yet it is a Roman mask of power decentred. Although he began his career as ascetic maestro and hyperliterate monk in Rome, most of Jerome's translationincluding his biblical translations-were accomplished after he left the city

I9 The complex mechanics involved in the production, and translation, of the Chronicon, are outlined in Grafton and Williams 2006: $133-77$.

20 The 'Comic' Terence mocked his rival Luscius Lavinius, who had produced ad verbum translations of Menander.

2 I Jerome's target is Ambrose: see Layton 2002; Hunter 2008: 234-42. 
(under strong encouragement (Cain 2009: 99-I28)). ${ }^{22}$ In the same preface to his translation of Didymus, Jerome writes:

When I dwelled in Babylon, and was a serf of the purple-clad prostitute, and I lived by the law of the Quirites, I wished to prattle a bit about the Holy Spirit, and began a little work dedicated to the pontiff of that city.... [but then] the Senate of the Pharisees raised a cry, and ... the whole gang of the unlearned - under cover of a doctrinal quarrel-conspired against me. So from there I returned to Jerusalem, like a homecoming; after the House of Romulus, and the Lupercalian games, I gazed upon Mary's inn and the Saviour's cave.... Called forth by you, here in Judea I murmur a song I could not sing in a foreign land (ibid).

By the 390s, Jerome was no longer Christianizing a Roman model of cultural power in the old capital: having relocated, as he put it, from 'Babylon' to 'Jerusalem' (or, more accurately, the suburb of Bethlehem), Jerome now minted a Roman style of cultural capital in the new Christian centre of the holy land. Yet even in this geographic and intellectual move, Jerome acts in supremely Roman fashion. Like a new Constantine building up a new Christian capital, Jerome appropriated and refurbished the tools of Old Rome in a New Jerusalem.

The geographic displacement, and intellectual appropriation, of Rome's cultural capital to Bethlehem allowed Jerome to extend his model of translational power. Adam Kamesar has alerted us to the Latin sensibility which led Jerome to transform Origen's project of a revised Septuagint into a full-fledged retranslation of the Old Testament iuxta Hebraeos (Kamesar I993: 43). This Latinity permitted Jerome to craft a masterful Christianity, which could encounter the 'other'-even in its 'native' province_ _ and bring home its 'captive meanings.' By the time of his repatriation to Bethlehem, Jerome had begun to appreciate Origen's allegory of Deut 2 I:IO-I3, the 'beautiful captive slave woman' shorn and taken as a bride of Israel, to represent the Christian appropriation of paideia (Origen, Homiliae in Leviticum 7.6; Jerome, epp. 2 I.I3, 66.8, 70.2). Elsewhere I have described Jerome's transformation of Origen's translational projects, remade from the correction of the Septuagint into the elevation of the 'Hebrew truth' (hebraica veritas), as a form of late Roman Christian cultural imperialism (Jacobs 2004: 67-I00). By the late 390s, secure from his monastic perch in Bethlehem, Jerome was engaging in a variety of edifying projects fashioned to bolster both his own intellectual value and that of Roman Christianity. He produced commentaries, ascetic treatises, and-throughout it all-translations, that most basic currency of his cultural economy.

\section{Rufinus's challenge}

That translation should be both the starting point and undercurrent of Jerome's epistolary shoot-out with Rufinus, then, should not surprise: at work is a broader

22 In a neat reversal, although Rufinus had spent more than two decades as a monk in Jerusalem, his translation of the Peri archōn and subsequent conflict with Jerome was conducted after his return to Italy: for detailed chronology, see Hammond I977. 
debate over the intersection of Christian erudition and power. While it is unclear how Rufinus felt about Jerome's view of such cultural capital before the controversy over Origen's writings, his feelings crystallize in its midst. The first book of Rufinus's Apology against Ferome comprises a disgruntled defence of his own orthodoxy, an explanation of the innocent circumstances in which he came to translate Origen's Peri archōn, and a detailed exposition of Jerome's persistent, and hypocritical, use of Origen's problematic theology. Already, Rufinus bristles at Jerome's posture as the artistic translator-he sneeringly refers to him as 'rhetor noster' (c. Hier. I.Io) $)^{23}$ - disavowing any Ciceronian or Horatian artistry by flatly saying the 'simple task of the translator [is to] change Latin into Greek' (penitus modum interpretis et ex Graeco in Latinum vertentis) (c. Hier. I.I5). Rufinus paints himself as talentless, expressly rejecting any authority from his position as mediator of Greek works into Latin. His linguistic pretensions are so muted that he (perhaps overly) modestly suggests he originally begged off of the translation project because 'my Latin speech had grown stiff through almost thirty years of neglect' (c. Hier. I. I I).

Modest protestations complete, Rufinus goes on the offensive. At issue is the very element of Jerome's translations which the monk of Bethlehem found valuable: the mastery and exportation of 'other' (that is, non-Christian) knowledge. Rufinus recalls Jerome's famous, and melodramatic, renunciation of 'secular books' during his sojourn in the Syrian desert-during which Jerome renounced 'Ciceronianism' before the tribunal of the Lord (ep. 22.30) - and calls Jerome on his hypocrisy: 'Set among tortures and beatings, he swears that he will never again have nor read from secular books. But now, I ask, look over the things he has written, see if there is a single page of his work where he does not confess himself a Ciceronian, where he does not say, 'But our Cicero. ..' 'but our Horace. . ', 'but our Vergil. ..' (c. Hier. 2.7). Certainly Rufinus wishes to score points against Jerome for hypocrisy, but there is also the more sweeping devaluation of cultural capital at work here: Jerome's attempts to cash in on 'the classics' is portrayed as being truly disloyal to that heavenly tribunal.

Likewise, Rufinus faults Jerome's citation of Greek sources: first, for its simple crassness and dishonesty (e.g., c. Hier. 2.7: 'he boasts that he has read the Pythagorean books, which learned men assure are not extant'); but, secondly, for inappropriately attempting to parlay secular capital into Christian authority: “'Chrysippus' and 'Aristides,' 'Empedocles' and the rest of the names of Greek authors he scattered around his readers like so much vapour and clouds, in order that he may seem learned and more well-read' (ibid.). Jerome deserves special condemnation, according to Rufinus, for claiming to have been introduced to logic through Porphyry's Eisagoge - 'Porphyry,' he sneers, 'who was the special enemy of Christ' (c. Hier. 2.9). The references to Porphyry put a point on Jerome's Ciceronian hypocrisy, since Rufinus claims Jerome could not even read Greek

23 As Rufinus was probably aware, Cicero preferred the term orator to the Greek loan-word rhetor (Orator 3.12). 
when he made his broken vow before the dream tribunal. Jerome shows how much his love of 'human knowledge' surpasses his love of Christ by seeking out the pagan author responsible for treatises attacking Christ, the New Testament, and Christianity.

At this point Rufinus can bring in Jerome's reliance on Palestinian Jewish teachers, a further valuation of foreign knowledge over Christian faith. Jerome had castigated Rufinus for being 'self-taught,' implying that he produced knowledge of an inferior value (ep. 84.3: nec iuxta quorundam praesumptionem ipse me docui). Rufinus, in turn, denigrates knowledge acquired from outside the Christian fold (c. Hier. 2.15). The one Jewish teacher Jerome had previously named, Bar Hanina (or Baraninas), Rufinus rechristens to underscore Jerome's erudite faithlessness:

But why should I stupidly list Christian men [as my teachers]? It's not because of them that he says I am self-taught, but because I didn't receive Barabbas as a teacher from the synagogue, and I wasn't introduced to logic through Porphyry's Eisagoge. Forgive me for this, that I preferred to seem ignorant and unlearned, rather than be called the disciple of Barabbas! (c. Hier. 2.1 5; see Jacobs 2004: 83-90)

Jerome had claimed his knowledge held value - the philosophy of the Greeks, the linguistic and scriptural knowledge of the Jews - precisely because its otherness had been appropriated and mastered by a Christian. Rufinus rejects Jerome's imperialist model of cultural capital.

Rufinus then devalues the very act of translation which lay at the root of Jerome's acquisition of public worth. First, Rufinus claims, Jerome's knowledge of Greek is nothing special: 'It does not follow that a holy and prudent person who is Latin will have sufficient familiarity with the Greek language. Nor does it detract from his sanctity if he lacks familiarity with a foreign language (peregrinae linguae)' (c. Hier. 2.35). Rufinus then refuses to cede to Jerome the hallowed Christian translators he had invoked in his treatise on translation, arguing that sainted Latins like Hilary of Poitiers 'translated nothing... from the Greek' (ibid.) Not only does Jerome think himself superior to monolingual Latin Christians, in his new biblical translations he outstrips the apostles themselves:

Did Peter, Christ's apostle, deceive the Church, and hand over to it false books that contained nothing of the truth and, although he knew that what was true was possessed among the Jews, he wished for what was false to be possessed among the Christians?. . But let us concede that Peter the apostle could not do what this one [i.e., Jerome] has recently done, what do we say about Paul? Was Paul also illiterate? A 'Hebrew of Hebrews,' a Pharisee according to the Law, educated at the feet of Gamaliel, who, when he was stationed in Rome, if Peter was deficient, do you think he couldn't make up for it? (c. Hier. 2.37-8)

Rufinus mocks Jerome's language of true and counterfeit learning: Jerome, with his partner-in-crime Barabbas, have at long last decked out the Church in 'true ornaments' (ornamenta vera), that is, the 'Jewish fables and genealogies' that she so long 
lacked: 'so now, after 400 years, the truth of the Law comes forth to us, bought at a price from the synagogue!' (c. Hier. 2.39) Even Origen-whom Jerome still attempted to invoke as a precedent for his translations - never thought to foist a Jewish Bible on Christianity, instead carefully isolating the knowledge of 'others' from Christian truth by means of the physically separated columns of his Hexapla (c. Hier. 2.40).

Jerome's model of linguistic conquest and cultural capital is not only impious, Rufinus concludes, but dangerous, contaminating Christianity with letters that kill instead of life-giving spirit. Rufinus even inverts Jerome's earlier language of 'captive Greek senses', writing:

Yours therefore, my brother, yours is this deed, and it is clear that no one from the church has been your companion or ally in it, except that one alone whom you so frequently call to mind, Barabbas. Who else would dare tamper with the instruments handed down to the church from the apostles, except a Jewish spirit? It is they, o my brother, most dear to me before you were captured by the Jews, they who have led you into such evils! (c. Hier. 2.4I)

As for Rufinus, the translation of 'other' knowledge brings him no credit, no capital on which he can trade against his fellow Christians: 'Neither animated by strife, nor desirous of glory, but prompted by fear of God, I transported a bounty of ancient materials to be used in buildings of a new construction, and old armour, already rusted shut, I polished up, not so I might instigate a civil war, but beat back an enemy one (hostile)' (c. Hier. 2.45). ${ }^{24}$

Jerome's apologetic response to Rufinus cedes little ground in the contest over intellectual bona fides, instead reinforcing the value of knowledge appropriated 'at great cost' (magno sumptu) from non-Christian sources (c. Ruf. 2.35, speaking specifically of the Jews). If Rufinus will mock Jerome for remaining a 'Ciceronian,' Jerome will in turn depict Rufinus as the very 'pattern of Catonian strictness' (c. Ruf. I.I3: norma Catonianae severitatis, on which see Lardet I993: 70-7I), holding to a higher, more artificial standard of cultural isolation than even Cato the Censor. If Rufinus will accuse Jerome of betraying Christianity in his reliance on pagan and Jewish knowledge, Jerome will simultaneously tar Rufinus as unlearned ('you had scarcely gotten the merest taste of oratory as a young man': $c$. Ruf. I.30) and insinuate that he has been studying Cicero on the sly to appear more learned than he is: 'you,' Jerome sneers, 'who seem to yourself a man of letters (litteratulus) and a Rabbi!' (ibid.). It is Rufinus who is the 'rabbi,' the literary climber, the poseur. Ultimately, however, Jerome's darkest accusation against Rufinus will be that all of his intellectual efforts amount to no more than disingenuous pretence and that, in putting forward his translation of Origen's Peri archōn, Rufinus in fact acted as a counterfeiter in the cultural economies of Christian faith.

24 Note there is still a sense of intellectual spolia here. 
Jerome both reinforces his own imperial view of cultural capital and paints Rufinus as a counterfeiter by emphasizing a uniquely Christian element of the value of erudite translation: the unmasking of heresy. Jerome had earlier laid groundwork for this view when he acted as a kind of 'court translator' for the Greek anti-Origenist Bishop Theophilus of Alexandria in the early 4oos. Now, against Rufinus, he claims these translations were made 'for the edification of the church' (c. Ruf. 3.I6). Discussing his retranslation of Origen's problematic treatise, Jerome boasts: 'for this did I translate, so that I might expose the evil of what was translated. Do you think I'm just a translator? I'm a betrayer [proditor]. I betrayed the heretic, so that I might free the church from heresy' (c. Ruf. I.7) ${ }^{25}$ Jerome's intellectual achievement now acts as an authoritative filter for Christian knowledge: 'My work had a twofold use: both to reveal the author as a heretic, and to disclose the translator as false [non verus]' (ibid.). ${ }^{26}$ Jerome's translations prove a gold standard against the production of counterfeit capital.

Part of Jerome's criticism of Rufinus is straightforward mockery, especially in Book I. On the one hand, Rufinus - self-taught and poorly educated-likes to pretend that he is a renowned genius of the Christian world, when he is actually little-known outside of his tiny circle of followers (c. Ruf. I.9, I.Io, I.I7, I.30, 2.9-II). The fact that Rufinus (in contrast to Jerome) was a 'previously unknown' (ignotus prius) translator makes the scandal of his translation that much more evident (c. Ruf. т.8). Jerome criticizes Rufinus's sloppy and uneducated 'editorial' translation policy: 'You were asked to turn Greek into Latin, not to correct it; to produce someone else's words, not compose your own!' (c. Ruf. 2.I I). Yet more than mere ignorance has led Rufinus to foist his poor translation on the West, Jerome says: 'No one objects to you for having translated Origen, otherwise Hilary and Ambrose will be held up on this same charge; but because you translated heretical things, and you strengthened your case with the praise in the preface' (c. Ruf. 2.I4, repeated at 3.I4). Jerome's major complaint is that Rufinus, in pretending to be a 'mere' translator, has done much more: as he explained in his preface to his translation, and an earlier treatise On the Adulteration of the Works of Origen, Rufinus operated on the principle that heretics had altered and corrupted Origen's texts. Where Rufinus found passages incongruent with what he knew of Origen's opinions and orthodoxy, he excised them. What's more, Rufinus claimed that Jerome preceded him in this editorial endeavour (Praefatio in Periarchōn I.I). Jerome rejects both claims. Rufinus has produced knowledge that seems to have value, and even tried to validate it with the stamp of Jerome's approval, an act of deliberate counterfeit cultural production. Otherwise, why the textual games? Does Rufinus wish to translate Origen? Then stick to his commentaries (as Jerome has done). Does Rufinus wish

25 Proditor is used to describe Judas Iscariot in Luke 6: 16.

26 Rufinus accused Jerome of usurping exactly this prerogative, as the 'judge' of all Christian writers: Rufinus, c. Hier. 2.34. 
to reveal Origen's heresies to the West (as Jerome now too has done)? Then 'change nothing from the Greek, and indicate this in your preface' (c. Ruf. 2.14).

In Book 3, written after Jerome has seen Rufinus's own apology, Jerome reiterates his main points: Rufinus must be a heretic, because he has attempted to smuggle heresy into the West. Jerome refers to Rufinus's translation of Pamphilus's Defence of Origen, which Jerome insists is a heretical forgery now given Latin life by Rufinus's malice: 'Scandal in Greece wasn't enough for you, unless you can inflict it on Latin ears, and deform a celebrated martyr as much as you can by your translation' (c. Ruf. 3.I2). Good translators-like Hilary, Ambrose, and Jerome himself - take care to show the good and the bad, not boast, as Rufinus did, that they had 'cut out the worst and left the best' (c. Ruf. 3. I4). Rufinus may claim ignorance, or modesty, or simplicity, but Jerome has now revealed him: 'You call yourself innocent, whose translation made Rome quake in fear.... Only you can translate the poison of heretics, and raise a toast to all the nations from the chalice of Babylon' ( $c$. $R u f .3 .2 \mathrm{I}, 3.25)$. In the face of Rufinus's counterfeit cultural capital, the entire city of Rome (apparently) demanded the real thing from Jerome: 'Rome was said to have been turned upside-down by your translation; everyone was asking me for a remedy for it' (c. Ruf. 3.37; see also 3.36). Jerome stepped into the role that Rufinus had (sincerely, or sarcastically) granted to him in the preface that started it all: as the model of 'eloquence' and translational authority by which Greek riches are conveyed to Roman ears (Rufinus, Praefatio in Periarchōn I.I), the ultimate arbiter between real and counterfeit Christian cultural capital.

\section{Conclusions}

Jerome and Rufinus continued to translate, even after the heat of the controversy had passed, both continuing to cash in on the intellectual status accorded to the bilingual (or, as Rufinus tagged Jerome, 'trilingual' (Jerome, c. Ruf. 3.6, referring to a lost letter of Rufinus)) educated Christian. Yet their brief, and fierce, debates in the early 400 demonstrate that even within a recognized system of cultural capital, the value of such capital could be highly contested. Jerome, drawing on the intellectual pedigree of the founders of the Roman Empire, sought to Christianize a distinctly Roman cultural economy, in which he claimed the power to appropriate, transmit, and judge the vast quantity of 'other' knowledge that could support Christian intellectual domination. The knowledge of others - heretics, pagans, Jews - were all the stuff of potential Christian capital, to be conspicuously seized and transferred into Christian terms.

Rufinus, on the other hand, seems to be positing a different, perhaps distinctly Christian, approach to 'other' knowledge. In his own translations, and certainly in his defence to Jerome, Rufinus resisted any claim of masterful appropriation, deeming it arrogant and dangerous. For Rufinus, translation was a humble act of fellowship through which only appropriate Christian documents should be transmitted. Soon after translating Origen's Peri Archōn (and drawing Jerome's wrath), Rufinus translated from Greek the Sentences of Sextus, a set of philosophical aphorisms which 
Rufinus attributed to Pope Sixtus II, an early Christian bishop and martyr (episcopi et martyris gloria decoratus: Rufinus, Sententiae Sexti praefatio). ${ }^{27}$ The very Christianness of these bits of otherwise recognizably Greek paideia is crucial for Rufinus, translating for an ascetic couple: 'it seems quite suitable (revera aequum) for one who, for God's Word, earthly ornaments have become but filth, that she now be adorned by us (a nobis) instead with necklaces of the Word and Wisdom' (ibid.). Christian gems in place of the sordid paideia of the past will fittingly bedeck ascetic souls. Rufinus himself is barely visible in this chain of transmission, the mere mediator of clear, Christian speech: 'in open and sufficiently plain speech I have turned Sextus into Latin (aperto et satis plano sermone Sextum in Latinum verti)' (ibid).

Of course, we might read Rufinus's Christianization of the Sentences of Sextus as itself a sort of wilful, and masterful, Christianization of pagan paideia. It was as clear to Jerome in the decade after Rufinus's death as it has been for modern scholars that the Sentences should be ascribed not to a martyred bishop of Rome, but rather to a famous Pythagorean philosopher (Jerome, ep. I33.4, comm. in Hezechielem 6 (18:5-6); Chadwick 1959: I I7-37). The fact that Rufinus erases his own agency, both as translator and Christianizer of ancient, useful paideia perhaps signals to us that he was not so different from the ancient Latin translators of Greek art, such as Cicero or Horace. Renunciation of power, the invisible hand of mastery, was also a long-held tradition among Roman elites, particularly suited to the ascetic authority cultivated by men such as Rufinus (Burrus I995). In Rufinus's very subtle transfer of cultural capital, no overt act of appropriation or transformation is visible, no gesture of Christian power made evident. 'Other' knowledge penetrates into Christian circles, but cleaned and baptized into the process of translation.

It is impossible — and, possibly, unhelpful - to try to discern whose view of the economic scale of Christian cultural capital 'won the day': Jerome's ostentatious and imperial appropriation, or Rufinus's selective and asceticized transformation of 'other' knowledge. The importance lies, rather, in the contest over knowledge itself: the desire, and resistance, to the appropriation of 'other' knowledge and the claims to power (visible or hidden) attendant upon the seemingly mundane act of translation. Jerome's and Rufinus's views of cultural capital, while antagonistic, are also in some way complementary: between them, they have broken apart into discrete formulations the ways in which Christians can fittingly appropriate and transmit non-Christian knowledge. Just as ascetic Christianity itself could contain the paradoxical values of triumph and humility, so too Christian knowledge could be at once imperious and self-effacing. We witness, perhaps, not opposite poles but rather possible sites on a spectrum of political paideia. Between the political capital of Rome

27 According to Hammond i977: 386-9 (see also the chart on p. 428), Rufinus translated the Peri archōn in $397-8$, soon after his return to Italy from the East. The translation of the Sententiae Sexti was executed in the year 400 , by which time Rufinus had also received Jerome's angry denunciation of Rufinus's translation (Jerome, ep. 84), leading Rufinus to finish writing his Apologia contra Hieronymum by the year $40 \mathrm{o}$. 
and the religious centres of the holy land, the 'battle of words' (repugnantem ad haec verba: c. Ruf. 3.9) that was waged in the early decades of a Christian Roman Empire rearticulated the fields of politics, erudition, and piety that would characterize the possibilities of religious politics in the ensuing centuries.

\section{References}

W. Adler, 'Ad Verbum or Ad Sensum: the Christianization of a Latin translation formula in the fourth century', in John C. Reeves and John Kampen (eds), Pursuing the Text: Studies in Honor of Ben Zion Wacholder on the Occasion of his Seventieth Birthday (Sheffield: Sheffield Academic Press, I994), pp. $32 \mathrm{I}-48$.

C. Ando, The Matter of the Gods: Religion and the Roman Empire (Berkeley: University of California Press, 2008).

L. Ayres, Nicaea and its Legacy: An Approach to Fourth-Century Trinitarian Theology (Oxford: Oxford University Press, 2004).

G. J. M. Bartelink, Hieronymus: Liber de Optimo Genere Interpretandi (Epistula 57), Ein Kommentar (Leiden: Brill, I980).

F. Biville, 'The Graeco-Romans and Graeco-Latin: a terminological framework for cases of bilingualism', in J. N. Adams, Mark Janse and Simon Swain (eds), Bilingualism in Ancient Society: Language Contact and the Written Text (Oxford: Oxford University Press, 2002), pp. 77-I02.

P. Bourdieu, Distinction: A Social Critique of the Fudgement of Taste, trans. By Richard Nice (Cambridge: Harvard University Press, I984).

— L Language and Symbolic Power, ed. by John B. Thompson, trans. By Gino Raymond and Matthew Adamson (Cambridge: Harvard University Press, I99I).

- Outline of a Theory of Practice, trans. By Richard Nice (Cambridge: Cambridge University Press, I977).

- The Field of Cultural Production, ed. and intro by Randal Johnson (New York: Columbia University Press (I993).

P. Bourdieu and J. C. Passeron, Reproduction in Education, Society, and Culture, trans. By Richard Nice (London: Sage Publications, I977).

S. Brock, 'Aspects of translation technique in antiquity', Greek, Roman, and Byzantine Studies, 29 (I979), pp. 69-87.

G. H. Brown, 'The meanings of Interpres in Aldhelm and Bede', in Perio Boitani and Anna Torti (eds), Interpretation: Medieval and Modern (Bury St. Edmunds: D.S. Brewer, I993), pp. 45-56.

V. Burrus, The Making of a Heretic: Gender, Authority, and the Priscillianist Controversy (Berkeley: University of California Press, I995).

A. Cain, The Letters of Jerome: Asceticism, Biblical Exegesis, and the Construction of Christian Authority in Late Antiquity (Oxford: Oxford University Press, 2009).

A. Cameron, 'Education and literary culture', in Averil Cameron and Peter Garnsey (eds), The Cambridge Ancient History, vol. I3: The Late Empire A.D. 337-425 (Cambridge: Cambridge University Press, I998), pp. 665-707.

H. Chadwick, The Sentences of Sextus: A Contribution to the History of Early Christian Ethics (Cambridge: Cambridge University Press, I959).

C. M. Chin, Grammar and Christianity in the Late Roman World (Philadelphia: University of Pennsylvania Press, 2007).

E. A. Clark, Ferome, Chrysostom and Friends: Essays and Translations (New York: Edwin Mellen Press, I979).

- The Origenist Controversy: The Cultural Construction of an Early Christian Debate (Princeton: Princeton University Press, I992).

A. Corbeill, 'Education in the Roman Republic: creating traditions', in Yun Lee Too (ed.), Education in Greek and Roman Antiquity (Leiden: Brill, 200I), pp. 26I-87.

P. Courcelle, Late Latin Writers and their Greek Sources, trans. By Harry E. Wedeck (Cambridge: Harvard University Press, I969).

C. Edwards and G. Woolf (eds), Rome the Cosmopolis (Cambridge: Cambridge University Press, 2003). 
S. Goldhill (ed.), Being Greek Under Rome: Cultural Identity, the Second Sophistic, and the Development of Empire (Cambridge: Cambridge University Press, 200I).

A. Grafton and M. H. Williams, Christianity and the Transformation of the Book: Origen, Eusebius, and the Library of Caesarea (Cambridge: Harvard University Press, 2006).

J. Guillory, Cultural Capital: The Problem of Literary Canon Formation (Chicago: University of Chicago Press, I993).

C. P. Hammond, 'The last ten years of Rufinus' life and the date of his move south from Aquileia', Journal of Theological Studies, n.s, 28 (I977), pp. 372-429.

L. Holtz (ed.), Donat et la tradition de l'enseignement grammatical: Étude sur l' 'Ars Donati' et sa diffusion (IVe-IXe siècle) et édition critique (Paris: CNRS, I98I).

D. Hunter, Marriage, Celibacy, and Heresy in Ancient Christianity: The fovinianist Controversy (Oxford: Oxford University Press, 2008).

A. S. Jacobs, Remains of the Fems: The Holy Land and Christian Empire in Late Antiquity (Stanford: Stanford University Press, 2004).

J. Kaimio, The Romans and the Greek Language (Helsinki: Societas Scientiarum Fennica, 1979).

A. Kamesar, Ferome, Greek Scholarship, and the Hebrem Bible: A Study of the Quaestiones Hebraicae in Genesim (Oxford: Oxford University Press, I993).

R. Kaster, Guardians of Language: The Grammarian and Society in Late Antiquity (Berkeley: University of California Press, I988).

P. Lardet, L'apologie de férôme contre Rufin: Un commentaire (Leiden: Brill, I993).

R. A. Layton, 'Plagiarism and lay patronage of ascetic scholarship: Jerome, Ambrose, and Rufinus', Journal of Early Christian Studies, Io (2002), pp. 489-522.

L. S. Nasrallah, Christian Responses to Roman Art and Architecture: The Second-Century Church Amid the Spaces of Empire (Cambridge: Cambridge University Press, 2010).

S. Rebenich, Hieronymus und sein Kreis: Prosopographische und sozialgeschichtliche Untersuchungen (Stuttgart: Franz Steiner Verlag, I992).

B. Rochette, 'Du grec au latin et du latin au grec: Les problèmes de la traduction dans l'antiquité grécolatine', Latomus, 54 (I995), pp. 245-6I.

A. Seele, Römische Übersetzer, Nöte, Freiheiten, Absichten: Verfahren des literarischen Übersetzens in der griechisch-römischen Antike (Darmstadt: Wissenschaftliche Buchgesellscaft, I995).

S. Swain, 'Bilingualism in Cicero? The evidence of code-switching', in J. N. Adams, Mark Janse and Simon Swain (eds), Bilingualism in Ancient Society: Language Contact and the Written Text (Oxford: Oxford University Press, 2002), pp. I28-67.

Y. L. Too (ed.), Education in Greek and Roman Antiquity (Leiden: Brill, 200I).

M. Vessey, 'Jerome and Rufinus', in Frances Young, Lewis Ayres and Andrew Louth (eds), The Cambridge History of Early Christianity Literature (Cambridge: Cambridge University Press, 2004), pp. 3i $8-27$.

— ' 'Jerome's Origen: the making of a Christian literary persona', Studia Patristica, 28 (I993), pp. I35-45.

G. Vidal, Fulian: A Novel (Boston: Little, Brown, I964).

E. J. Watts, City and School in Late Antique Athens and Alexandria (Berkeley: University of California Press, 2006).

T. Whitmarsh, Greek Literature and the Roman Empire: The Politics of Imitation (Oxford: Oxford University Press, 200I).

- The Second Sophistic (Oxford: Oxford University Press, 2005).

M. H. Williams, The Monk and the Book: Ferome and the Making of Christian Scholarship (Chicago: University of Chicago Press, 2006).

M. Wolf and A. Fukari (eds), Constructing a Sociology of Translation (Amsterdam: John Benjamins, 2007).

C. Zirkle, 'Animals impregnated by the wind', Isis, 25 (I936), pp. 95-130. 